\title{
USE OF MULTIPLE ANTIMICROBIAL DRUGS BY CLINICAL PATIENTS: A PROGNOSTIC INDEX OF HOSPITAL MORTALITY?
}

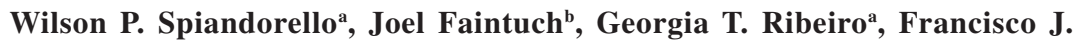
Karkow $^{c}$, and Jacqueline O. Alvares ${ }^{\mathrm{a}}$

Spiandorello WP, Faintuch J, Ribeiro GT, Karkow FJ, Alvares JO. Use of multiple antimicrobial drugs by clinical patients: a prognostic index of hospital mortality? Clinics. 2006;61(1):15-20.

PURPOSE: To quantify the use of multiple and prolonged antibiotics and anti-infective drug therapy in clinical patients in a 144bed hospital.

METHODS: Adult patients (2,790 patients with 3,706 admissions over a period of 19 months) were investigated prospectively regarding treatment with anti-infective agents. The mean age was 57.4 (range, 18.8 - 97 years), and 54.3\% were females (2012). RESULTS: Hospital stay was 5.5 (6.7 days (range, 2 - 226 days), with duration up to 10 days for 91.9\% of the subjects. Antibiotics or other agents were administered to 1,166 subjects (31.5\%), $325(8.8 \%)$ required assistance in the ICU, and a total of 141 (3.8\%) died. The association between anti-infective drug therapy and hospital mortality was statistically significant $(P<.01)$ with a strong linear correlation $(\mathrm{r}=0.902, P=.014)$. The quantity of prescribed antimicrobial drugs, age, and need for ICU assistance were independent variables for death by logistic regression analysis. The odds ratio for anti-infective drug therapy was 1.341 (1.043 to 1.725); for age, 1.042 ( 1.026 to 1.058); and for stay in the ICU, 11.226 ( 6.648 to 18.957).

CONCLUSIONS: 1) The use of large amounts of anti-infective drug therapy was associated with higher hospital mortality according to both univariate and logistic regression analysis; 2) The adverse influence was less marked than that of hospitalization in ICU but of a similar order of magnitude as age; 3) Further studies should elucidate whether infectious foci, noninfectious morbidity, or drug effects underlie this undesirable concurrence .

KEYWORDS: Antibiotics. Antimicrobial therapy. Antibiotic association. Multiple antibiotics. Hospital prognosis. Hospital mortality.

\section{INTRODUCTION}

Prognostic determinators are valuable tools for assessing outcome in various disease contexts. When included in validated protocols, they may help in the allocation of scarce resources and manpower, in the elimination of re-

anfection Control Committee, Hospital do Círculo, Caxias do Sul/RGS, Brazil

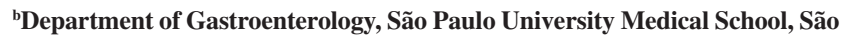
Paulo/SP, Brazil

'Department of Surgery, Caxias do Sul University Medical School, Caxias do Sul/RGS, Brazil

Email: wilsonsp@terra.com.br

Received for publication on July 07, 2005.

Accepted for publication on November 07, 2005. dundant tests or therapies, and in auditing clinical results, thus helping in cost containment and increased efficacy of hospital care. Scoring systems also provide a useful means of comparing results of different institutions. ${ }^{1}$

Various scoring systems have been developed in efforts to quantify the risk for a patient from a disease or an intervention. The majority address critical illness, trauma, pancreatitis, surgery, and other life-threatening situations, but protocols for nonsurgical hospitalized patients are available as well. ${ }^{2}$

In surgical candidates, the American Society of Anesthesiology classification (ASA) ${ }^{3}$ is probably the simplest and most traditional assessment, whereas few scoring methods match the popularity of the APACHE series 
in intensive care units. ${ }^{4-5}$ Trauma score or TRISS are a mainstay of initial evaluation in emergency units along with the Glasgow coma score, ${ }^{6-8}$ but multiple other standardizations exist, based on physiologic, ${ }^{9,10}$ nutritional, ${ }^{11,12}$ septic, ${ }^{13}$ and other ${ }^{14}$ criteria.

Single measurements have also been consistently endorsed in infections, cardiovascular diseases, hepato-pancreatic conditions, major surgery, and various clinical contexts. ${ }^{15-22}$ One rather unusual study ${ }^{23}$ reported that the surgeon's "gut feeling" was also a good indicator of subsequent outcome in the case of major procedures. A recent report evaluated blood transfusion effects on mixed venous oxygen saturation and lactate levels in patients with SIRS/ sepsis. $^{24}$

Prognostic equations based on monitoring interventions, therapeutic requirements, and need for nursing care include the Therapeutic Intervention Scoring System (TISS) and the simplified TISS-28, ${ }^{25}$ the Nurses Intervention Classification (NIC) ${ }^{26}$ and others. ${ }^{27}$

Use of antibiotic or multiple anti-infective agents in clinical patients is not part of any known prognostic marker, neither singly nor in association with other indicators. Yet, infectious diseases alone, or with comorbidities that might require such prescriptions are not uncommonly observed in hospitalized subjects, and aggressive prescriptions could be a marker of poor outcome. Therefore, a prospective investigation was designed to evaluate the impact of such intervention on hospital mortality.

\section{METHODS}

Setting: The study was performed in a 144-bed private general hospital. Most adult specialties were represented, including AIDS, but with frequencies for trauma, burns, chronic renal failure, and transplanted subjects was low.

Study design - A prospective controlled cohort observational study involving clinical wards of the entire institution was carried out. During 19 months, between July 2002 and December 2003, the use of all prescribed antibiotics and anti-infective agents in nonsurgical services was recorded, and compared with hospital mortality.

Experimental hypothesis: Use of multiple or prolonged anti-infective drug therapy is associated with hospital mortality.

AIMS: 1) To quantify the anti-infective agents used in hospitalized patients 2) To correlate such use, and especially the use of multiple agents or prolonged use with the hospital mortality rate.

Inclusion criteria:

- Age $>18$ years, males or females

- General wards or intensive care unit
- Prophylactic or therapeutic indication

- Single or multiple drugs

- Exclusion criteria

- Surgical cases

- Death or discharge before 48 hours

Stratification: Patients were stratified into Group I ( $\mathrm{n}=$ 1,166 ) and controls (Group II, $\mathrm{n}=2,540$ ). The test group encompassed all clinical cases admitted to the hospital wards during the study period who received 1 or more antiinfective drugs. Controls were similar patients hospitalized at the same period who in the view of the responsible internist did not require antimicrobial therapy.

Clinical methods: The following variables were analyzed: age, gender, total length of hospital admission, hospitalization in the intensive care unit (ICU), number of prescriptions for anti-infective agents, duration of anti-infective therapy, mortality.

Study protocol: Patients were recruited at admission and followed till discharge or death. In case of multiple admissions, each hospitalization was considered a new case, and all statistics refer to admissions, not to individuals, unless stated otherwise.

For the purposes of this investigation anti-infective agents included antibiotics as well as antifungal and antiviral substances. If more than 1 product was used during hospitalization, either in association or sequentially, a multiple-agent situation was documented.

Ethical procedures: This study was approved by the Ethical Committee of the Hospital.

Statistical tests: Values are shown as mean \pm SD. Statistical analysis was done using the SPSS software package, version 10.0. Variables with a normal distribution, confirmed by the Kolmogorov-Smirnov test, such as age, hospitalization period, and number of drugs used, were compared using 2-tailed analysis of variance (ANOVA) confirmed by Tuckey post-hoc test, as well as by the Student $t$ test. Discrete variables (gender, admittance to the ICU, and mortality) were investigated using the chi-square test. Linear regression analysis (Pearson) was applied to identify relevant clinical correlations, and correlation between antibiotic administration and death was determined by logistic regression analysis. A significance level of 5\% $(P<$ .05) was adopted in all circumstances.

\section{RESULTS}

A total of of 2,790 patients with 3,706 admissions was studied. Hospital stay was $5.5 \pm 6.7$ days (range, 2 - 226), with duration up to 10 days in $91,9 \%$ of the subjects. Age was $57.4 \pm 18.8$ years (range, $20-97$ ), and $54.3 \%$ were females (2012). 
Antibiotics or other agents were administered to 1,166 admitted patients (31.5\%); 325 (8.8\%) required assistance in the ICU, and a total of 141 (3.8\%) died. Groups I and II had similar age $(57.8 \pm 20.1$ versus $56.7 \pm 18.2$ years, $P=.136)$ and gender distribution $(54.1 \%$ versus $54.4 \%, P=.886)$.

Among those prescribed antibiotics and related drugs, the great majority received a single anti-infective agent, but as many as 5 or more such drugs were occasionally necessary (Table 1). Age distribution according to number of anti-infective agents administered is shown in Table 2.

Table 1 - Anti-infective drugs in the treated population (Test group, $\mathrm{n}=1166$ )

\begin{tabular}{lcc}
\hline Number of drugs & Patients & Percentage \\
\hline 1 & 849 & $72.8 \%$ \\
2 & 231 & $19.8 \%$ \\
3 & 54 & $4.6 \%$ \\
4 & 14 & $1.2 \%$ \\
5 or more & 18 & $1.5 \%$ \\
\hline
\end{tabular}

Table 2 - Age distribution according to number of antiinfective agents administered (Test group, $\mathrm{n}=1166$ )

\begin{tabular}{lccc}
\hline Number of drugs & Patients & Age & Confidence interval \\
\hline 1 & 849 & $59.0 \pm 19.9$ & $57.7-60.4^{*}$ \\
2 & 231 & $53.5 \pm 20.1$ & $50.9-56.1^{*}$ \\
3 & 54 & $56.8 \pm 19.7$ & $51.4-62.2$ \\
4 & 14 & $48.8 \pm 17.1$ & $38.9-58.7$ \\
5 or more & 18 & $62.4 \pm 22.3$ & $51.3-73.6$ \\
\hline (*) Age difference between 1 and 2 anti-infective agents administered, $P$ \\
$=.002$.
\end{tabular}

There was no difference in gender among the subgroups in Table 2, but the age of the groups was different $(P=$ .002 , ANOVA). The Tuckey test revealed that this difference was due to the difference between subgroups 1 and 2 , patients in subgroup 2 ( 2 antimicrobial drugs) being significantly older than those in subgroup 1 ; other groups were small and did not permit adequate analysis. Nevertheless, no progressive age pattern could be identified for increasing numbers of prescriptions, as those requiring more substances were not systematically older or younger than those taking one agent alone.

An association between number of anti-infective agents and hospital death was found to be significant (Table 3). This association is illustrated in Figure 1, representing the regression analysis for anti-infective drug therapy versus death frequency. The correlation was very strong (Pearson coefficient, $\mathrm{r}=0.902, P=.014$; adjusted determination coefficient $\mathrm{r}^{2}=0.766$ ).

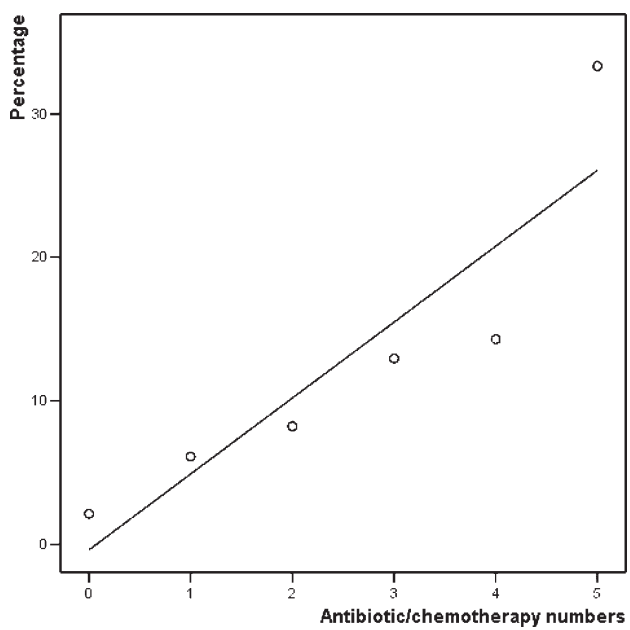

Figure 1 - Linear correlation line of number of anti-infective agents versus fatal outcome (all patients, $\mathrm{n}=3706$ )

Hospitalization in the ICU did not correlate with increased numbers of prescribed anti-infective drugs $(P=.731)$. Among the 1,166 patients that were antibiotic managed, 105 were admitted to intensive care, and corrrepondingly, 220 of the 2,540 patients who remained free from anti-infective drug therapy were also admitted to the ICU $(9.0 \%$ versus $8.7 \%, \mathrm{NS})$. Nevertheless, ICU cases had significantly higher mortality $(18.8 \%$ versus $2.4 \%$ mortality, $P<.01)$.

Surviving patients were younger (56.6 \pm 18.8 years) than those who died $(69.2 \pm 15.4, P<.01)$, but gender was not

Table 3 - Hospital mortality according to number of anti-infective agents (All patients, $n=3,706$ )

\begin{tabular}{|c|c|c|c|c|}
\hline Number of antimicrobial drugs & Patients & Mortality (absolute) & Mortality (\%) & Significance* \\
\hline \multicolumn{5}{|l|}{ Control Group } \\
\hline 0 & 2,540 & 54 & $2.1 \%$ & \\
\hline \multicolumn{5}{|l|}{ Test group } \\
\hline 1 & 849 & 52 & $6.1 \%$ & \\
\hline 2 & 231 & 19 & $8.2 \%$ & $P<.01$ \\
\hline 3 & 54 & 7 & $13.0 \%$ & \\
\hline 4 & 14 & 2 & $14.3 \%$ & \\
\hline 5 or more & 18 & 7 & $33.3 \%$ & \\
\hline
\end{tabular}

(*) Univariate analysis, in comparison with controls 
Table 4 - Logistic regression variables of hospital mortality (All patients, $n=3706$ )

\begin{tabular}{|c|c|c|c|c|c|}
\hline Description & Beta coefficient & $\mathrm{SE}^{*}$ & Significance & Odds ratio & Confidence interval \\
\hline Number of drugs & 0.294 & 0.128 & $P<.02$ & 1.341 & $1.043-1.725$ \\
\hline Age & 0.041 & 0.008 & $P<.01$ & 1.042 & $1.026-1.058$ \\
\hline ICU stay & 2.418 & 0.267 & $P<.01$ & 11.226 & $6.648-18.957$ \\
\hline Anti-infective days & 0.049 & 0.008 & $P<.01$ & 1.050 & $1.033-1.067$ \\
\hline Age & 0.38 & 0.006 & $P<.01$ & 1.039 & $1.027-1.051$ \\
\hline ICU stay & 2.025 & 0.190 & $P<.01$ & 7.576 & $5.222-10.993$ \\
\hline
\end{tabular}

Obs: $\mathrm{SE}=$ Standard error

different $(P=.259)$. Their hospitalization period was also shorter, as would be expected $(5.3 \pm 6.5$ versus $10.7 \pm 10.9$ days, $P<.01)$, in parallel with their days on antibiotic/antiinfective drugs ( $2.3 \pm 5.6$ versus $7.9 \pm 12.3$ days, $P<.001$ ).

Logistic regression analysis of hospital mortality in the present model, based on the variables selected by univariate correlation, revealed that anti-infective drug load measured by 2 different criteria, along with age and hospitalization in the ICU, were significant and independent factors. Those criteria as previously explained were number of days on anti-infective drugs and number of administered anti-infective drugs, and they were closely related measurements $(\mathrm{r}$ $=0.738, P<.01)$. Consequently, it was appropiate to use either one or the other, but not both in the same regression equation. Odds ratio pointed out anti-infective drug load and age $(34.1 \%$ and $4.2 \%$ increased probability of mortality, respectively) as moderate prognostic indices. Odds ratio for hospitalization in the ICU, however, was incomparably stronger, reaching a probability of death of $1,122.6 \%$ higher than controls. The 2 sets of results are reproduced in Table 4.

\section{DISCUSSION}

A single infectious disease may be the reason for the demise of a previously healthy person. Microbial sequelae that appear in the natural history of other diseases, as frequently seen in hospitalized patients, contribute even more frequently to the causes of therapeutic failure, especially in intensive care units. ${ }^{5,10,13}$

Diagnostic uncertainty occurs, and inappropriate prescription could result from wrong assumptions within dangerous conditions. One noteworthy example is the disagreement surrounding the concept of ventilator-associated pneumonia. $^{28-30}$

A rise in inappropriate use of anti-infective drugs, in parallel or not with controversies concerning diagnosis or prognosis, is reported in some studies. ${ }^{31-33}$ In fact, there are professionals who advocate the principle: "if in doubt, reinforce anti-infective drug therapy."
The more critically ill subjects, presumably with more demonstrated septic problems, were possibly those targeted by associations, or sequential changes of anti-infective medications. A slightly elevated death rate would thus be a consequence of partial and incomplete relief of their supposedly worse clinical condition, not of therapeutic misuse. If so, generous antimicrobial drug prescriptions should be associated with more ICU admissions, but that percentage was not different from the control subjects in this study.

In the experience of Wilson et $\mathrm{al}^{34}$ with anaerobic bacteremia, polymicrobial infection was one of the variables that was significantly associated with mortality in the univariate analysis. Interestingly, multivariate testing did not support this assumption, as only age (similarly to the results of this study) along with liver disease were confirmed negative factors.

Inappropriate antibiotic administration, but not necessarily of multiple agents, was a mechanism for increased mortality in the series of community-acquired pneumonia presented by Johnson et al. ${ }^{35}$ Adequate antibiotics were highlighted as a weakly positive prognostic factor in the large investigation of meningococcal disease by Barquet et al, ${ }^{36}$ whereas age $>60$ years was found to have markedly ominous implications.

Multiple or consecutive introductions of anti-infective drugs could be harmful by augmentation of side effects, or by damage to defense systems via destruction of normal microbial flora, or by disruption of immunologic reactions.

Hecker et al, ${ }^{37}$ studying the redundant use of antibiotics, found out that erroneous treatment of noninfectious syndromes or nonbacterial entities was the second most frequent explanation for $30 \%$ of hospital drug misuse, generating economic and clinical losses.

Substitution of skin or enteric microbial flora by resistant bacteria or by fungi is a possibility, and potentially deleterious effects of antibiotics on the immunologic system, although uncommon, have been reported. Tsimmerman and Mikhaleva $^{38}$ found an immunosuppressive action of antibiotics during treatment of Helicobacter pylori and duodenal ulcer. Vesce et $\mathrm{al}^{39}$ identified inhibition of IL- 6 and pros- 
taglandin E2 in amniotic fluid secondary to ampicilin introduction. Stem cell mobilization can diminish during the use of antibiotics acting on intestinal flora. ${ }^{40}$ In an inflammatory bowel model, Colpaert et $\mathrm{al}^{41}$ described potentially undesirable cytokine-modulating effects of metronidazol.

Logistic regression analysis in the current circumstances left little doubt that the anti-infective drug load, measured by 2 different criteria, was a significant and independent factor for hospital mortality. It must be emphasized that the numerical weight of the anti-infective drug load was somewhat greater than that of age $(34.1 \%$ versus $4.2 \%$ increased probability of mortality), but of the same order of magnitude. In contrast, hospitalization in the ICU had by far the strongest deleterious impact as assessed by odds ratio: 1,122. 6\% augmented risk. Similar findings corresponded to days on anti-infective drug therapy, and all findings were statistically significant.

Lack of stratification of patients according to primary disease, severity score, classes of antibiotics, and interval until death was a weakness in the design of this study. These variables deserve additional studies.

\section{CONCLUSIONS}

It is concluded that: 1) A heavy load of anti-infective drugs was associated with higher hospital mortality according to both univariate and logistic regression analysis; 2) The adverse influence was less marked than that of hospitalization in ICU but of similar order of magnitude as age; 3) Further studies should elucidate whether this results from serious infections per se despite appropriate drug utilization, or whether therapeutic misjudgment in the form of unrecognized microbial foci, drug effects, or other noninfectious morbidity underlies this undesirable concurrence.

\section{RESUMO}

Spiandorello WP, Faintuch J, Ribeiro GT, Karkow FJ, Alvares JO. Uso de múltiplos antimicrobianos por pacientes clínicos. Um índice prognóstico de mortalidade hospitalar. Clinics. 2006;61(1):15-20.

OBJETIVOS: Tendo como propósito quantificar o uso múltiplo ou prolongado de antibióticos e quimioterápicos antimicrobianos em pacientes clínicos, um estudo prospective foi executado em um hospital de 144 leitos.

MÉTODOS: Enfermos adultos tratados com antibióticos e quimioterrápicos anti-infecciosos (2.790 pacientes com 3.706 internações) foram investigados. A duração da hospitalização foi de 5,5 $\pm 6,7$ dias (2 -226), sendo o prazo de até 10 dias em $91,0 \%$ da população. A idade era de 57.4 \pm 18.8 anos $(20-97)$, e $54.3 \%$ eram mulheres (2.012). Antibióticos e outros agentes foram administrados a 1.166 indivíduos (31,5\%); 325 (8,8\%) necessitaram de assistência na unidade de terapia intensiva, e no total $141(3,8 \%)$ faleceram.

RESULTADOS: A associação entre medicação antiinfecciosa e mortalidade hospitalar foi estatisticamente significativa $(p<0,01)$ com forte correlação linear $(r=$
0,902, $\mathrm{p}=0,014)$. A quantidade de antimicrobianos prescritos, a idade e o requerimento de cuidados intensivos foram variáveis independentes para óbito na regressão logística. O cálculo do "odds ratio" para a medicação analisada assinalava probabilidade de desfecho negativo de 1,341 (1,043 a 1,725) para múltiplos antimicrobianos, para a idade de 1,042 (1,026 a 1,058), e para admissão na UTI de $11,226(6,648$ a 18,957$)$.

CONCLUSÕES: 1) O uso de grandes quantidades de agentes antimicrobianos associou-se com mortalidade hospitalar aumentada tanto pela análise univariada como na regressão logística; 2) Seu efeito adverso foi menos marcado que o associado à internação na unidade de cuidados intensivos, porém de magnitude semelhante ao da idade; 3) Estudos adicionais são necessários para elucidar se este resultado indesejável se prende à ação de focos infecciosos subjacentes, à morbidade não infecciosa ou aos efeitos colaterais das drogas utilizadas,

UNITERMOS: Antibióticos. Quimioterapia anti-microbiana. Associação antibiótica. Múltiplos antibióticos. Prognóstico hospitalar. Mortalidade hospitalar.

\section{REFERENCES}

1. Kiran RP, Delaney CP, Senagore AJ. Preoperative evaluation and risk assessment scoring. Clin Colon Rectal Surg. 2003;16:75-84.

2. Menke H, Klein A, John KD, Junginger T. Predictive value of ASA classification for the assessment of perioperative risk. Int Surg. 1993;78:266-70.
3. Knaus WA, Zimmerman JE, Wagner DP, Draper EA, Lawrence DE. APACHE-acute physiology and chronic health evaluation: a physiologically based classification system. Crit Care Med. 1981;9:591-7.

4. Knaus WA, Draper EA, Wagner DP, Zimmerman JE. APACHE II: a severity of disease classification system. Crit Care Med. 1985;13:818-29. 
5. Knaus WA, Wagner DP, Draper EA, Zimmerman JE. The APACHE III prognostic system. Risk prediction of hospital mortality for critically ill hospitalized adults. Chest. 1991;100:1619-36.

6. Champion HR, Sacco WJ, Carnazzo AJ, Copes W, Fouty WJ. Trauma score. Crit Care Med. 1981;9:672-6.

7 Champion HR, Sacco WJ, Copes WS, Gann DS, Gennarelli TA, Flanagan ME. A revision of the Trauma Score. J Trauma. 1989;29:623-9.

8. Cho DY, Wong YC. Comparison of the APACHE III, APACHE II and Glasgow Coma Scale in acute head injury for prediction of mortality and functional outcome. Int Care Med. 1997;23:77-84.

9. Le Gall JR, Loirat P, Alperovitch A. A simplified acute physiology score for ICU patients. Crit Care Med. 1984;12:975-7.

10. Barbieri S, Michieletto E, Feltracco P. Prognostic systems in intensive care: TRISS, SAPS II, APACHE III. Minerva Anestesiol. 2001;67:51938.

11. Buzby GP, Mullen JL, Matthews DC, Hobbs CL, Rosato EF. Prognostic nutritional index in gastrointestinal surgery. Am J Surg. 1980;139:160-7.

12. Harvey KB, Moldawer LL, Bistrian BR, Blackburn GL. Biological measures for the formulation of a hospital prognostic index. Am J Clin Nutr. 1981;34:2013-22.

13. Elebute EA, Stoner HB. The grading of sepsis. Br J Surg. 1983;70:29-31.

14. Copeland GP, Jones D, Walters M. POSSUM: a scoring system for surgical audit. Br J Surg. 1991;78:355-60.

15. Blanco Quiros A, Casado Flores J, Nieto Moro M, Garrote Adrados JA, Arranz Sanz E, Asensio Anton J . Meningococcal sepsis in pediatrics. Parameters associated with poor outcome. An Pediatr (Barc). 2004; 61:305-13.

16. Fichtlscherer S, Breuer S, Zeiher AM. Prognostic value of systemic endothelial dysfunction in patients with acute coronary syndromes: further evidence for the existence of the "vulnerable" patient. Circulation. 2004;110:1926-32.

17. Abraham NS, Young JM, Solomon MJ. Meta-analysis of short-term outcomes after laparoscopic resection for colorectal cancer. Br J Surg. 2004;91:1111-24.

18. Conway DS, Buggins P, Hughes E, Lip GY. Prognostic significance of raised plasma levels of interleukin-6 and C-reactive protein in atrial fibrillation. Am Heart J. 2004;148:462-6.

19. Hasegawa T, Hashikawa SN, Nakamura T, Torii K, Ohta M. Factors determining prognosis in streptococcal toxic shock-like syndrome: results of a nationwide investigation in Japan. Microbes Infect. 2004;6:1073-7.

20. Chen HC, Tzaan WC, Lui TN. Spinal epidural abscesses: a retrospective analysis of clinical manifestations, sources of infection, and outcomes. Chang Gung Med. J 2004;27:351-8.

21. Baumann M, Witzke O, Canbay A, Patschan S, Treichel U, Gerken G, et al. Serum C3 complement concentrations correlate with liver function in patients with liver cirrhosis. Hepatogastroenterology. 2004;51:1451-3.

22. Silvestri A, Vitale C, Ferretti F, Onorati D, Fini M, Rosano GM. Plasma levels of inflammatory C-reactive protein and interleukin- 6 predict outcome in elderly patients with stroke. J Am Geriatr Soc. 2004;52:1586-7.

23. Hartley MN, Sagar PM. The surgeon's 'gut feeling' as a predictor of post-operative outcome. Ann R Coll Surg Engl. 1994;76(Suppl 6):S277_ S278.
24 Mazza BF, Machado FR, Mazza DD, Hassmann V. Evaluation of blood transfusion effects on mixed venous oxygen saturation and lactate levels in patients with SIRS/sepsis. Clinics. 2005;60(1):311-316.

25. Miranda DR, De Rijk A, Schaufeli W. Simplified Therapeutic Interventions Scoring System: the TISS-28 items-results from a multicenter study. Crit Care Med. 1996;24:64-73.

26. McCloskey JC, Bulechek GM. Nursing Interventions Classification (NIC). 3rd ed. St Louis: Mosby; 2000. p. 12-18.

27. Royal College of Nursing. Dependency Scoring Systems: Guidelines for Nurses. London: RCN; 1995. p. 22-32.

28. Waterer GW, Wunderink RG. Controversies in the diagnosis of ventilatoracquired pneumonia. Med Clin North Am. 2001; 85:1565-81.

29. Pugin J. Clinical signs and scores for the diagnosis of ventilatorassociated pneumonia. Minerva Anestesiol. 2002;68:261-5.

30. Keenan SP, Heyland DK, Jacka MJ, Cook D, Dodek P. Ventilatorassociated pneumonia. Prevention, diagnosis, and therapy. Crit Care Clin. 2002;18:107-25.

31. Wiffen PJ, Mayon White RT. Encouraging good antimicrobial prescribing practice: a review of antibiotic prescribing policies used in the South East Region of England. BMC Public Health. 2001;1(1):4.

32. Solomon DH, Van Houten L, Glynn RJ, Baden L, Curtis K, Schrager H Academic detailing to improve use of broad-spectrum antibiotics at an academic medical center. Arch Intern Med. 2001;161:1897-902.

33. Lettau LA. Antibiotic-use screening evaluations (ABUSE) for physicians and patients: featuring prizes and penalties for physicians. Infect Control Hosp Epidemiol. 2000;21:796-9.

34. Wilson JR, Limaye AP. Risk factors for mortality in patients with anaerobic bacteremia. Eur J Clin Microbiol Infect Dis. 2004;23:310-6.

35. Johnson D, Carriere KC, Jin Y, Marrie T. Appropriate antibiotic utilization in seniors prior to hospitalization for community-acquired pneumonia is associated with decreased in-hospital mortality. J Clin Pharm Ther. 2004;29:231-9.

36. Barquet N, Domingo P, Cayla JA, Gonzalez J, Rodrigo C, FernandezViladrich $\mathrm{P}$, et al. Prognostic factors in meningococcal disease. Development of a bedside predictive model and scoring system. Barcelona Meningococcal Surveillance Group. JAMA. 1997;278:491-6.

37. Hecker MT, Aron DC, Patel NP, Lehmann MK, Donskey CJ Unnecessary use of antimicrobials in hospitalized patients: current patterns of misuse with an emphasis on the antianaerobic spectrum of activity. Arch Intern Med. 2003;163:972-8.

38. Tsimmerman I S, Mikhaleva EN. The state of immune system and effects of current therapy and immunomodulators. Klin Med (Mosk). 2003;81:40-4

39. Vesce F, Pavan B, Lunghi L, Giovannini G, Scapoli C, Piffanelli A Inhibition of amniotic interleukin-6 and prostaglandin E2 release by ampicillin. Obstet Gynecol. 2004;103:108-13.

40. Velders GA, van Os R, Hagoort H, Verzaal P, Guiot HF, Lindley IJ Reduced stem cell mobilization in mice receiving antibiotic modulation of the intestinal flora: involvement of endotoxins as cofactors in mobilization. Blood. 2004;103:340-6.

41. Colpaert S, Liu Z, De Greef B, Rutgeerts P, Ceuppens JL, Geboes K Effects of anti-tumour necrosis factor, interleukin-10 and antibiotic therapy in the indometacin-induced bowel inflammation rat model Aliment Pharmacol Ther. 2001;15:1827-36. 